\title{
COVID-19 Pnömonisi Olan Hastanın Tosilizumab ile Tedavisi
}

\section{Treatment of the Patient with COVID-19 Pneumonia with Tocilizumab}

\author{
Özgür GÜNAL'1(ID), Hatice ÜDÜRGÜCÜ'(IDD), Ayșe ȘENBABA'(IID), Süleyman Sırrı KILIC̣'(İD)
}

\footnotetext{
${ }^{1}$ Sag̃lık Bilimleri Üniversitesi, Samsun Eg̃itim ve Araștırma Hastanesi, İnfeksiyon Hastalıkları ve Klinik Mikrobiyoloji Klinig̃i, Samsun, Türkiye
}

Makale atıfi: Günal Ö, Üdürgücü H, Şenbaba A, Kılı̧̧ SS. COVID-19 pnömonisi olan hastanın tosilizumab ile tedavisi. FLORA 2020;25(2):279-81.

\section{Sayın editör;}

Pnömoni, COVID-19'un sk görülen ve ciddi komplikasyonlarından birisidir. Hastalığın tanısında gercek zamanlı polimeraz zincir reaksiyonu (RTPCR) öncelikle kullanılmakla birlikte, hatalı negatiflik durumunda akciğer bilgisayarlı tomografi (BT) görüntülemesi COVID-19 hastalığının tedavisinde önemli bir rol oynamaktadır ${ }^{[1]}$. Daha ciddi olgularda siddetli akut solunum sendromu (SARS) gelisebilmektedir. Koronavirüs ile ilișkili SARS patogenezi, yüksek serum proinflamatuvar sitokin ve kemokinler [interlökinler 1,6 , 8 ve 12 (IL-1, IL-6, IL-8, IL-12), tümör nekroz faktörü-alfa (TNF- $\alpha$ ) ve interferon-gama (IFN- $\gamma)]$ içeren bir sitokin fırtınası ile ilișkilidir[2]. COVID-19 tedavisi için tüm dünyada çok sayıda ilaç araștırması yapılmaktadır. Günümüzde henüz etkili bir așı bulunamamıstır. Tedavi seçiminde genellikle iki seçenek söz konusudur; birinci seçenek erken dönemde antiviral tedavi ile virüsü baskılamak, diğeri ise ilerlemis hastalık tablosunda (yoğun bakım) IL-1 ve IL-6'nın sebep olduğu sitokin firtınasını kontrol etmektir. Özellikle ikinci aşamada kullanılacak ilaçların seçimi ve bașlanma zamanı cok kritiktir ${ }^{[3]}$. Son dönemde bir monoklonal antikor olan tosilizumab tedavisi özellikle ciddi seyreden COVID-19 pnömonisi tedavisinde önemli bir seçenek olarak kabul edilmektedir ${ }^{[4]}$.
Kırk dokuz yașında kadın hasta 6 Nisan tarihinde ates ve öksürük sikayeti ile acil servise bassururdu. Hastanın muayenesinde ates: $38.2^{\circ} \mathrm{C}$, tansiyon: 110/85 $\mathrm{mmHg}$, solunum hizı: $21 / \mathrm{dk}$ olarak saptanırken, laboratuvar tetkiklerinde; beyaz küre: $4400 \mathrm{~mm}^{3} / \mathrm{L}$ (4.5-10.5), total lenfosit: 1000 $\mathrm{mm}^{3} / \mathrm{L}$ (600-3400), prokalsitonin: $0.02 \mathrm{ng} / \mathrm{mL}(0-$ $0.5)$, C-reaktif protein: $37.9 \mathrm{mg} / \mathrm{L}(0-5)$, ferritin: 89.6 (13-150) ng/mL, D-dimer: 0.20 (0-0.5), karaciğer ve böbrek fonksiyonları normal olarak saptand. Hastaya cekilen akciğer BT'de; her iki akciğer orta ve alt zonlarda periferik yerleșimli fokal odaklar șeklinde buzlu cam görünümünde infiltrasyon alanları saptandı (Resim 1). Hastanın hikayesinde eși ve kızının da COVID-19 tanısıyla hastanede yattı̆̆ı öğrenildi. Hasta COVID-19 infeksiyonu ön tanısıyla infeksiyon hastallkları kliniğine yatırıld. Hastadan nazofarengeal sürüntü örneği alınıp SARS-CoV-2 virüs için RT-PCR testi gönderildi ve hidroksiklorokin tablet, azitromisin tablet ve faviripravir tablet tedavileri bașlandı. Yatısıının ikinci gününde ateși normale dönen ve takiplerinde bir sorun olmayan hastanın 11 Nisan günü ates yüksekliği $\left(38.5^{\circ} \mathrm{C}\right)$ ve takipnesi $(25 / \mathrm{dk})$ geliști. Oda havasında oksijen satürasyonu $\left(\mathrm{SaO}_{2}\right)$ : \%88 olması üzerine hastaya 4 $\mathrm{L} /$ dk'dan nazal $\mathrm{O}_{2}$ tedavisi bașland. Laboratuvar tetkiklerinde; beyaz küre: $7400 \mathrm{~mm}^{3} / \mathrm{L}$, lenfosit sa- 


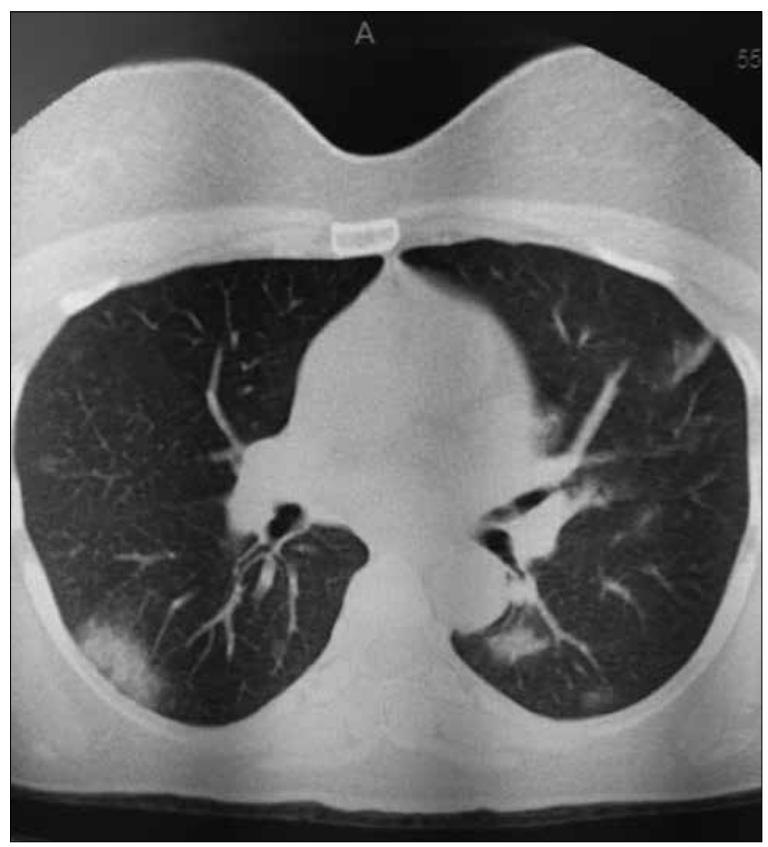

Resim 1. Her iki akciğer orta ve alt zonlarda periferik yerleşimli fokal odaklar şeklinde buzlu cam görünümünde infiltrasyon alanları.

yis1: $400 \mathrm{~mm}^{3} / \mathrm{L}$, CRP: $139 \mathrm{mg} / \mathrm{L}$, prokalsitonin: $0.03 \mathrm{ng} / \mathrm{mL}$, ferritin: $480 \mathrm{ng} / \mathrm{mL}$, D-dimer: 0.80 olarak saptanırken, $\mathrm{HBsAg}$, anti-HCV ve anti-HIV testleri negatif olarak saptandi. Cekilen kontrol akciğer BT'de; bilateral akciğer üst loblarda, sağda orta lobda ve her iki akciğer bazalde periferik yerleșimli cok sayıda fokal buzlu cam görünümü (mevcut infiltrasyon alanlarında artma) saptandı (Resim 2). Hastanın beyaz küre yüksekliği olmaması ve prokalsitonin değerinin yükselmemesi nedeniyle sekonder bakteriyel infeksiyon olasılığı dışlandı. Bunun üzerine hastaya ek olarak 11 ve 12 Nisan tarihlerinde 4 $\mathrm{mg} / \mathrm{kg} /$ gün (intravenöz infüzyon seklinde) dozunda tosilizumab tedavisi bașland. Hastanın 13 Nisan günü takiplerinde ateși olmadı ve solunum sıkıntısı düzeldi. Klinik ve laboratuvar bulgularında düzelme (beyaz küre: $7100 \mathrm{~mm}^{3} / \mathrm{L}$, lenfosit sayıs1: 860 $\mathrm{mm}^{3} / \mathrm{L}$, CRP: $49 \mathrm{mg} / \mathrm{L}$, prokalsitonin: $0.02 \mathrm{ng} /$ $\mathrm{mL}$, ferritin: $120 \mathrm{ng} / \mathrm{mL}$, D-dimer: 0.30) olan hasta 16 Nisan tarihinde hastaneden taburcu edildi. Hastanın takiplerinde alınan laboratuvar testlerindeki değisiklliler Tablo 1'de özetlenmiștir.

Ciddi COVID-19 pnömonisi olan hastalarda aș1r1 hipersitokinemi (IL-1, IL-6, IFN- $\gamma$ vb.) tablosuna bağlı olarak makrofaj aktivasyon sendromu (MAS) ve sekonder lenfositik lenfohistiyositozis tablosu geli-



Resim 2. Bilateral akciğer üst loblarda, sağda orta lobda ve her iki akciğer bazalde periferik yerleşimli çok sayıda fokal buzlu cam görünümü (mevcut infiltrasyon alanlarında artma).

sebilmektedir. Bu hastalarda SARS tablosunun yanı sira, ates, lenfadenopati, hepatosplenomegali, anemi ve koagülasyon fonksiyon bozuklukları olușabilmektedir. Laboratuvar bulgularında ise özellikle ardısık ölçümlerde CRP, ferritin, D-dimer değerlerinde artıs ve/veya lenfosit, trombosit sayılarındaki düsmelerin dikkate alınması gelișmekte olan MAS bulgularını yakalamak açısından önem tașımaktadır ${ }^{[5]}$. COVID-19 hastalarındaki MAS tablosunda özellikle IL-6 yüksekliği dikkat cekicidir. Bu nedenle bu hastaların tedavisinde sitokin süpresyon tedavileri gündeme gelmiștir ${ }^{[6]}$.

Tosilizumab, IL-6 monoklonal antagonisti olarak islev gösteren, romatoid artrit, juvenil idiyopatik artrit ve dev hücreli arterit gibi bazı otoimmün hastalıklarda kullanilan bir ajandır ${ }^{[7]}$. Tosilizumab, son dönemde ciddi COVID-19 pnömonisinde klinik iyileșmede ciddi faydaları gösterilmiș bir ilaç olarak gündeme gelmistir. Cin'de 21 siddetli COVID-19 pnömonisi olan 21 hasta üzerinde yapılan bir çalıșmada tosilizumab tedavisinin ciddi klinik faydaları olduğu bildirilmiștir ${ }^{[8]}$. Cellina ve arkadașları paylaștıkları olgu bildiriminde, 64 yașinda siddetli COVID-19 pnömonisi olan ve yatısının yedinci gününde ventilatör desteğine alınan hastaya, 12 saat arayla iki kez tosilizumab $(8 \mathrm{mg} / \mathrm{kg})$ tedavisi verdiklerini ve hastanın ventilatör desteğinin yavaș yavas kesildiğini 
Tablo 1. Hastanın kronolojik sıraya göre laboratuvar değerleri

\begin{tabular}{|c|c|c|c|}
\hline Tetkik (normal aralık) & 6 Nisan 2020 & 11 Nisan 2020 & 16 Nisan 2020 \\
\hline Beyaz küre (4.5-10.5 mm³/L) & 4400 & 7400 & 7100 \\
\hline Total lenfosit (600-3400 mm³/L) & 1000 & 400 & 860 \\
\hline Prokalsitonin (0-0.5 ng/mL) & 0.02 & 0.03 & 0.02 \\
\hline C-reaktif protein (0-5 mg/L) & 37.9 & 139 & 49 \\
\hline Ferritin $(13-150 \mathrm{ng} / \mathrm{mL})$ & 89.6 & 480 & 120 \\
\hline D-dimer $(0-0.5)$ & 0.20 & 0.80 & 0.30 \\
\hline
\end{tabular}

ve 14 gün içerisinde klinik ve radyolojik bulgularında bariz düzelme olduğunu bildirmișlerdir ${ }^{[4]}$. Michot ve arkadașları da benzer sekilde, SARS tablosunda olan ve ek komorbid hastalikları olan 42 yașındaki erkek hastada iki kez uygulanan tosilizumab tedavisine iyi yanıt aldıklarını bildirmișlerdir ${ }^{[9]}$. Ülkemizde Sağlık Bakanlığı Halk Sağlığı Müdürlüğü, COVID-19 İnfeksiyonu Rehberi'nde siddetli COVID-19 pnömonisi olan hastalarda tosilizumab tedavisini önermekte$\operatorname{dir}^{[10]}$. Biz de hastamızda solunum sıkıntısı, takipne ve akciğer BT'de infiltrasyonların arttığı dönemde 24 saat arayla intravenöz infüzyonla verilen tosilizumab (4 mg/kg/gün) tedavisi sonrasında hızlı bir sekilde takipne ve solunum sıkıntısının düzeldiğini gözlemledik.

Sonuc olarak, siddetli COVID-19 hastalarında, hastanın SARS tablosunun hemen bașında tosilizumab tedavisi uygulanmasının, hastaların ventilatör desteğine ihtiyacı azaltmada ve akciğer fonksiyonlarının iyileșmesinde etkili olduğu düșüncesindeyiz.

\section{ÇIKAR ÇATIȘMASI}

Yazarlar bu makale ile ilgili herhangi bir clkar catıșması bildirmemișlerdir.

\section{KAYNAKLAR}

1. Fang $Y$, Zhang $H$, Xie J, Lin $M$, Ying $L$, Pang $P$, et al. Sensitivity of chest CT for COVID-19: comparison to RTPCR. Radiology 2020, http://dx.doi.org/10.1148/radiol.2020200432).

2. Huang C, Wang Y, Li X, Ren L, Zhao J, Hu Y, et al. Clinical features of patients infected with 2019 novel coronavirus in Wuhan, China. Lancet 2020;395(10223):497-506.

3. Wang Z, Yang B, Li Q, Wen L, Zhang R. Clinical features of 69 cases with coronavirus disease 2019 in Wuhan, China. Clin Infect Dis 2020 Mar 16. pii: ciaa272. doi: 10.1093/ cid/ciaa272. [Epub ahead of print].
4. Cellina $M$, Orsi $M$, Bombaci F, Sala M, Marino P, Oliva G. Favorable changes of $C T$ findings in a patient with $\mathrm{CO}$ VID-19 pneumonia after treatment with tocilizumab. Diagn Interv Imaging (2020). https://doi.org/10.1016/j. diii.2020.03.010.

5. McGonagle $D$, Sharif $K, O^{\prime}$ Regan $A$, Bridgewood $C$. The role of cytokines including interleukin-6 in COVID-19 induced pneumonia and macrophage activation syndrome-like disease. 2020 Apr 3;102537. doi: 10.1016/j.autrev.2020.102537

6. Wan S, Yi Q, Fan S, Lv J, Zhang X, Guo L, et al. Characteristics of lymphocyte subsets and cytokines in peripheral blood of 123 hospitalized patients with 2019 novel coronavirus pneumonia (NCP). medRxiv 2020.20021832

7. Tufan A, Avanoğlu Güler A, Matucci-Cerinic M. COVID-19, immune system response, hyperinflammation and repurposing antirheumatic drugs. Turk J Med Sci 2020;50:620-32

8. Xu X, Han $M, L i T$, Sun W, Wang $D, F u B$, et al. Effective treat- ment of severe COVID-19 patients with tocilizumab. ChinaXiv 202003.00026v1.

9. Michot JM, Albiges L, Chaput N, Saada V, Pommeret $F$, Griscelli $F$, et al. Tocilizumab, an anti-IL6 receptor antibody, to treat COVID-19-related respiratory failure: a case report. Ann Oncol 2020 Apr 2. doi: 10.1016/j.annonc.2020.03.300. (Online ahead of print).

10. https://covid19bilgi.saglik.gov.tr/depo/rehberler/COVID-19_Rehberi.pdf.

\section{Yazıșma Adresi/Address for Correspondence}

Doç. Dr. Özgür GÜNAL

Sağlık Bilimleri Üniversitesi,

Samsun Eğitim ve Araștırma Hastanesi,

İnfeksiyon Hastalıkları ve Klinik Mikrobiyoloji Kliniği,

Samsun-Türkiye

E-posta: ozgurgop@yahoo.com 